\title{
An Empirical Analysis of the Taylor Rule and Its Application to Monetary Policy: A Case for the United Kingdom and Euro Area
}

\author{
Keshab Bhattarai ${ }^{1}$ (iD) \\ Matthew Carter ${ }^{2}$ \\ ${ }^{1,2}$ The Business School, University of Hull, Cottingham Road, Hull, HU6 7RX, United Kingdom \\ Email:K.R.Bhattarai@hull.ac.uh
}

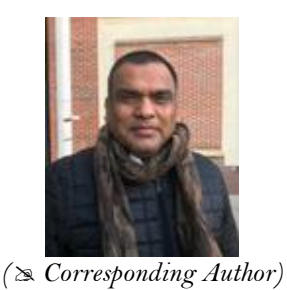

\begin{abstract}
This paper analyses the Taylor rule and its application to monetary policy in the United Kingdom and Euro area. The analysis uses a linear regression on quarterly economic data from 1993Q1 to 2017Q4 for the United Kingdom and 2000Q1 to 2016Q4 for the Euro area. The results show that the Taylor rule does not fully describe the monetary policy actions made by the Bank of England and European Central Bank over the period analysed; and, that both central banks engage in a significant level of interest rate smoothing. The results also suggest that the Taylor rule does not provide the rationale for quantitative easing within the two regions and that interest rates should be higher than they currently are.
\end{abstract}

Keywords: Interest rate rule, Taylor rule, Monetary policy, United Kingdom, Euro area.

JEL Classification: E43; E47.

Citation | Keshab Bhattarai; Matthew Carter (2018). An Empirical Analysis of the Taylor Rule and Its Application to Monetary Policy: A Case for the United Kingdom and Euro Area. Asian Journal of Economics and Empirical Research, 5(2): 173-182. History:

Received: 3 July 2018

Revised: 7 August 2018

Accepted: 11 September 2018

Published: 29 October 2018

Licensed: This work is licensed under a Creative Commons Attribution 3.0 License $($ co)

Publisher:Asian Online Journal Publishing Group
Contribution/Acknowledgement: Both authors contributed to the conception and design of the study.

Funding: This study received no specific financial support

Competing Interests: The authors declare that they have no conflict of interests.

Transparency: The authors confirm that the manuscript is an honest, accurate, and transparent account of the study was reported; that no vital features of the study have been omitted; and that any discrepancies from the study as planned have been explained.
stutures of the study have been omitted,

study as planned have been explained.
Ethical: This study follows all ethical practices during writing.

\section{Contents}

1. Introduction

5. Analysis of Results

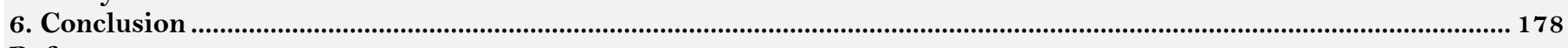

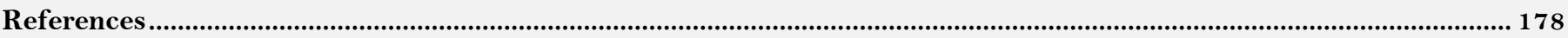

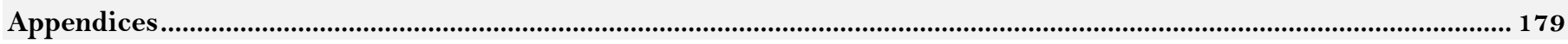




\section{Introduction}

Following the financial crisis there was a substantial shift in monetary policy. Central banks first responded by cutting interest rates to the zero lower bound. At the zero lower bound, conventional monetary policy fails to stimulate the economy and thus, central banks responded by implementing unconventional policies such as quantitative easing (Loide, 2014; Filardo and Nakajima, 2018). Over a decade since the financial crisis, monetary policy is yet to return to the norm; interest rates throughout developed nations remain close to the zero lower bound and central banks are still engaged in monetary policy. Several economists have argued that this extended period of low interest rates and unconventional monetary policy has failed to spur economic growth and instead hurt savers and lead to the formation of asset bubbles. Thus, it is useful to revisit the application of the Taylor rule throughout these abnormal times for monetary policy. By doing so, this paper aims to determine whether the Taylor rule adequately describes the monetary policy actions made by the Bank of England and European Central Bank throughout the period analysed. More specifically, this paper will aim to determine whether or not the Taylor rule advocates the extended period of unconventional monetary policy in these two regions.

\section{The Taylor Rule}

The original Taylor (1993) rule is a simple interest rate determination rule that approximates the responsiveness of the interest rate to the output gap and inflation gap (Castro, 2008). The original rule proposed by Taylor (1993) takes the following form:

$$
\mathrm{r}=\mathrm{p}+.5 \mathrm{y}+.5(\mathrm{p}-2)+2
$$

where: $\mathrm{r}=$ the nominal interest rate; $\mathrm{y}=$ the percentage deviation of real GDP from a target; $\mathrm{p}=$ the rate of inflation from the previous four quarters. The first constant that is inside the term $(p-2)$ is the Federal Reserve's target rate of inflation. The second constant is the assumed natural interest rate.

The rule states that if GDP exceeds potential GDP, or the level of inflation exceeds a target (assumed to be $2 \%$ ) that the interest rate should increase. Despite finding significant support for the Taylor rule in describing the actions of the federal reserve, Taylor (1993) noted that a central bank should not strictly follow an interest determination rule and instead use them as a guideline.

There is a significant level of support for the existence of a Taylor rule in previous literature. Taylor and Davradakis (2006); Cukierman and Muscatelli (2008) found evidence that the Bank of England followed a nonlinear Taylor rule. Cukierman and Muscatelli (2008) and Kulikauskas (2014) found similar evidence for the European Central Bank. Maza and Sanchez-Robles (2013) found that the Taylor rule perfectly fit the monetary policy actions of the European Central Bank between 1999 to 2002 and 2007 to 2009.

Lee et al. (2013) found that there were sizeable shifts in the Bank of England's monetary policy following the financial crisis. Haug and Nesse (2016) found that monetary policy had been either too strict or neutral for the Euro area following the financial crisis. Similarly, Alcidi et al. (2016) found that monetary policy was too loose until 2008 and then too tight in 2009 and 2010.

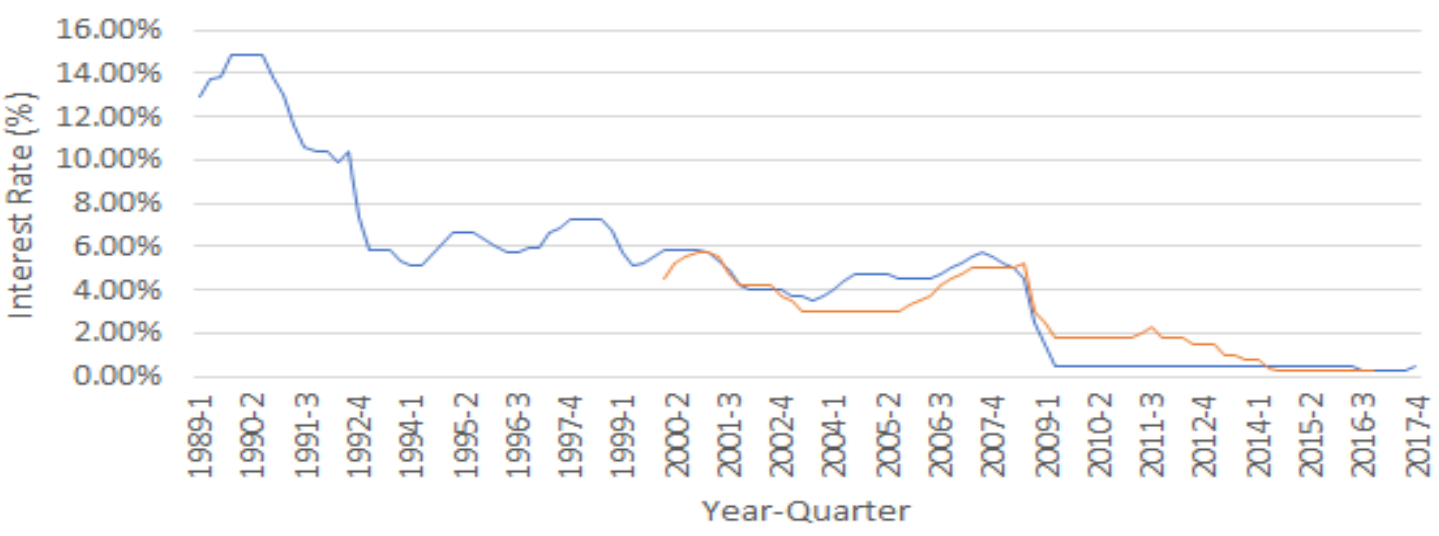

Bank Rate _ Marginal Lending Facility

Figure-1. A comparison of the Bank Rate and Marginal Lending Facility

Source: Bank of England (2018),Federal Reserve Economic Data (2018).

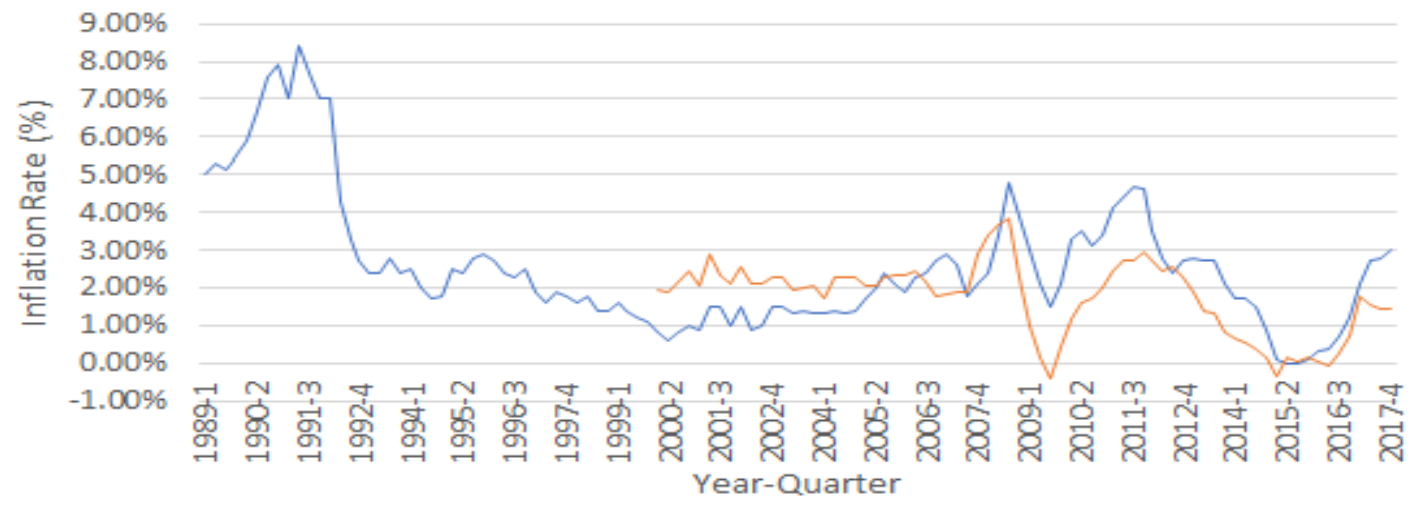

UK Inflation _ EA Inflation

Figure-2. Inflation rates for the United Kingdom and Euro Area

Source: Office of National Statistics (2018), ECB Statistical Data Warehouse (2018) 
Source: ONS (2016).

Figure-3. GDP For the United Kingdom (Millions of Pounds)

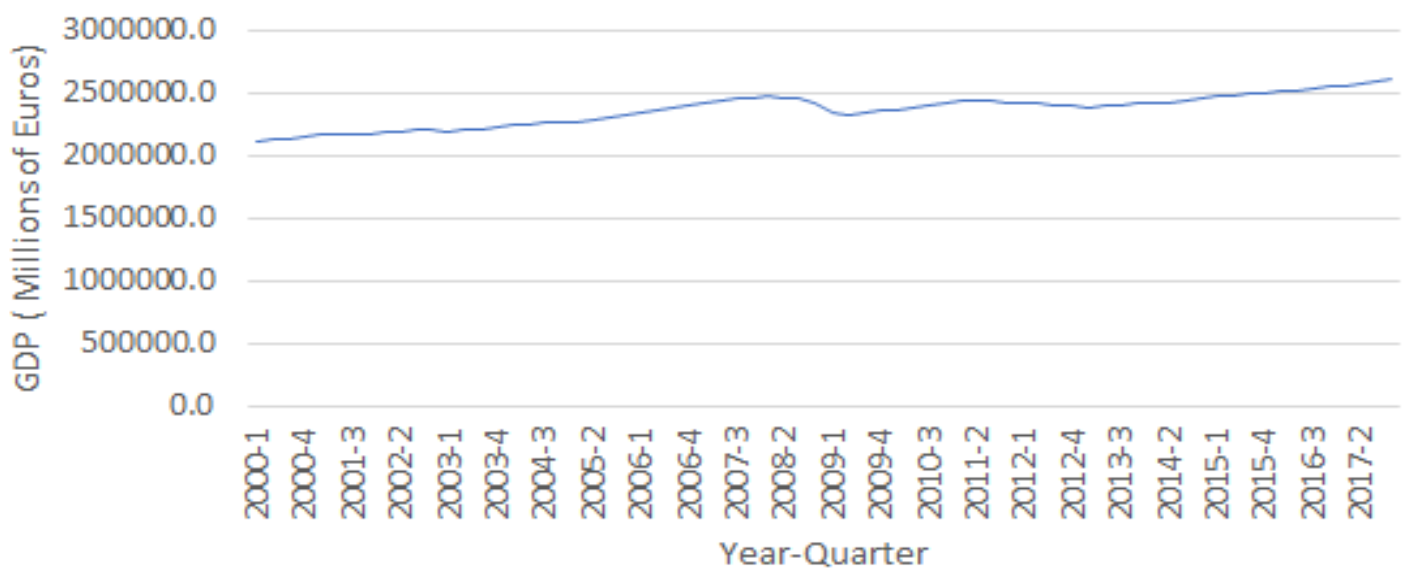

Source: ECBSDW (2018)

Figure-4. GDP for the Euro Area (Millions of Euros)

Nikolsko-Rzhevskyy and Papell (2012) found that the Taylor rule did not prescribe negative interest rates and thus did not provide the rationale for quantitative easing following the financial crisis.

Woodford (2001) suggested that the Taylor rule could be improved by incorporating the historical behavior of the variables in the rule. Coibion and Yuriy (2011) and Driffill and Rotondi (2007) attempted to account for interest rate smoothing by adding a lagged interest rate variable to the original Taylor rule. Both found that the coefficient of the lagged variable tended to be large and significant.

\section{Data}

This paper analyses quarterly economic data from 1993Q1 to 2017Q4 for the United Kingdom and 2000Q1 to 2016Q4 for the Euro area. The period analysed for the Euro area is shorter as the European Central Bank has only conducted monetary policy since 1999 (González-Páramo, 2005).

Interest rate time-series of the Official Bank Rate and the Marginal Lending Facility are used to estimate the Taylor rule throughout this analysis and are shown in Figure 3. The data for the Official Bank Rate and Marginal Lending Facility are collected from the Bank of England (2018) website and FRED (2018) respectively. As Figure 3 shows, interest rates have varied substantially over the period analysed. However, since the financial crisis, interest rates in both the United Kingdom and Euro area have remained close to the zero lower bound as central banks try to stimulate the economy.

Figures 2, 3 and 4 show the inflation rate and the level of GDP in the United Kingdom and Euro area which are used alongside the respective interest rates to estimate the Taylor rule throughout the analysis. Figure 2 shows the volatility of the inflation rate, especially throughout the financial crisis. In addition, there is a clear dip in Figure 3 and 4 which represent the reduction in GDP following the financial crisis. This paper uses CPI as the measure of inflation.

The inflation rate data and GDP data are collected from the ONS (2018) for the United Kingdom and the ECBSDW (2018) for the Euro area. Both GDP time-series are chain linked to account for the effects of inflation (ONS, 2016).

\section{Models}

This paper will estimate two models for the United Kingdom and Euro area. The first, the original (Taylor, $1993)$ rule, can be constructed using three equations. The first states the output gap $\left(\mathrm{Y}_{\mathrm{t}}-\mathrm{Y}_{\mathrm{t}}{ }^{*}\right)$ as a function of the deviation of the previous periods interest rate from the target rate $\left(\mathrm{i}_{\mathrm{t}-1}-\mathrm{i}^{*}\right)$. This relationship is negative as a higher interest rate decreases investment and spending thus causing the economy to contract such that:

$$
\mathrm{y}_{\mathrm{t}}-\mathrm{y}_{\mathrm{t}}{ }^{*}=-\mathrm{d}\left(\mathrm{i}_{\mathrm{t}-1}-\mathrm{i}^{*} \mathrm{t}\right) \quad \mathrm{d}>\mathrm{O} \text {. }
$$

where $y_{t}$ and $y_{t}{ }^{*}$ are the actual and potential levels of output; $i_{t-1}$ is the previous periods interest rate and $i^{*}{ }_{t}$ is the target interest rate. 
The second equation, the expectations-augmented Phillips curve, shows how price levels respond to a change in aggregate supply and is given by:

$$
\pi_{\mathrm{t}}=\pi_{\mathrm{t}}^{*}+\mathrm{c}\left(\mathrm{y}_{\mathrm{t}-1}-\mathrm{y}^{*} \mathrm{t}-1\right) \quad \mathrm{c}>0
$$

Where $\pi_{\mathrm{t}}$ and $\pi_{\mathrm{t}}^{*}$ are the actual and target rates of inflation; $\mathrm{y}_{\mathrm{t}}$ and $\mathrm{yt}_{\mathrm{t}}{ }^{*}$ are the actual and potential levels of output in the previous period. The Taylor rule can be derived by combining these equations such that:

$$
\mathrm{i}_{\mathrm{t}}=\mathrm{i}_{\mathrm{t}}^{*}+\mathrm{a}\left(\mathrm{Y}_{\mathrm{t}}-\mathrm{Y}_{\mathrm{t}}^{*}\right)+\mathrm{b}\left(\pi_{\mathrm{t}}-\pi_{\mathrm{t}}^{*}\right) \quad \mathrm{a}>0 ; \mathrm{b}>0
$$

where $i_{t}$ is the interest rate; $\left(\mathrm{Y}_{\mathrm{t}}-\mathrm{Y}_{\mathrm{t}}{ }^{*}\right)$ is the output gap; $\left(\pi_{\mathrm{t}}-\pi_{\mathrm{t}}{ }^{*}\right)$ is the inflation gap ; $\mathrm{i}_{\mathrm{t}}{ }^{*}$ is the natural interest rate and $\mathrm{a}$ and $\mathrm{b}$ are parameters and both are positive constants.

This model shows how policymakers should increase the interest rate if the output level raises above the potential or the inflation rate rises above the target (Bhattarai, 2008).

Based on Coibion and Yuriy (2011) and Driffill and Rotondi (2007) results we will estimate a second model to account for interest rate smoothing. The Taylor rule that was derived previously will be modified to incorporate a lagged interest rate variable such that:

$$
i_{t}=i_{t}^{*}+a\left(Y_{t}-Y_{t}^{*}\right)+b\left(\pi_{t}-\pi_{t}^{*}\right)+i_{t-1} \quad a>0 ; b>0
$$

where $i_{t-1}$ is the previous periods interest rate; all other constants and variables are the same as mentioned previously.

\section{Analysis of Results}

The estimated Taylor rules for both the United Kingdom $\left(\mathrm{R}^{2}=0.37\right)$ and Euro area $\left(\mathrm{R}^{2}=0.47\right)$ had a weak fit to the data. This is expected as the interest rate in an economy is influenced by more than just the output gap and inflation gap (Bhattarai, 2008). The part of interest setting that is not accounted for by the interest rate or output gap could be explained by these other variables (Loide, 2014). As noted by Coibion and Yuriy (2011); Driffill and Rotondi (2007) and Loide (2014) the weak fit could also be explained by interest rate smoothing.

The relationship between the interest rate and output gap for the United Kingdom (1) and Euro area (2) are as follows:

$$
\begin{gathered}
\mathrm{i}_{\mathrm{t}}=0.04+0.16\left(\mathrm{Y}_{\mathrm{t}}-\mathrm{Y}_{\mathrm{t}}^{*}\right)+1.24\left(\pi_{\mathrm{t}}-\pi_{\mathrm{t}}^{*}\right)(1) \\
(\mathrm{P} \text { value })\left(7.2 \times 10^{-25}\right)(0.07) \quad\left(1.4 \mathrm{X} 10^{-11}\right) ; \mathrm{R}^{2}=0.37 \\
\mathrm{i}_{\mathrm{t}}=2.89+7.76\left(\mathrm{Y}_{\mathrm{t}}-\mathrm{Y}_{\mathrm{t}}^{*}\right)+1.17\left(\pi_{\mathrm{t}}-\pi_{\mathrm{t}}^{*}\right) \quad(2) \\
(\mathrm{P} \text { value })\left(7.66 \times 10^{-28}\right)(0.33) \quad\left(5.4 \mathrm{X}_{1} 0^{-28}\right) ; \mathrm{R}^{2}=0.47
\end{gathered}
$$

The interest rate rises with the output gap and inflation gap for both the United Kingdom and Euro area, which is expected based on the literature. In both models, the inflation gap was highly statistically significant at $\mathrm{p}$ $<0.001$ however, the output gap was statistically insignificant. This result in line with Loide (2014) who also found that the output gap was insignificant to their model. Moreover, as primary objectives both the Bank of England and European Central Banks are to maintain price stability; it is expected that they would place more emphasis on the inflation gap when setting monetary policies.
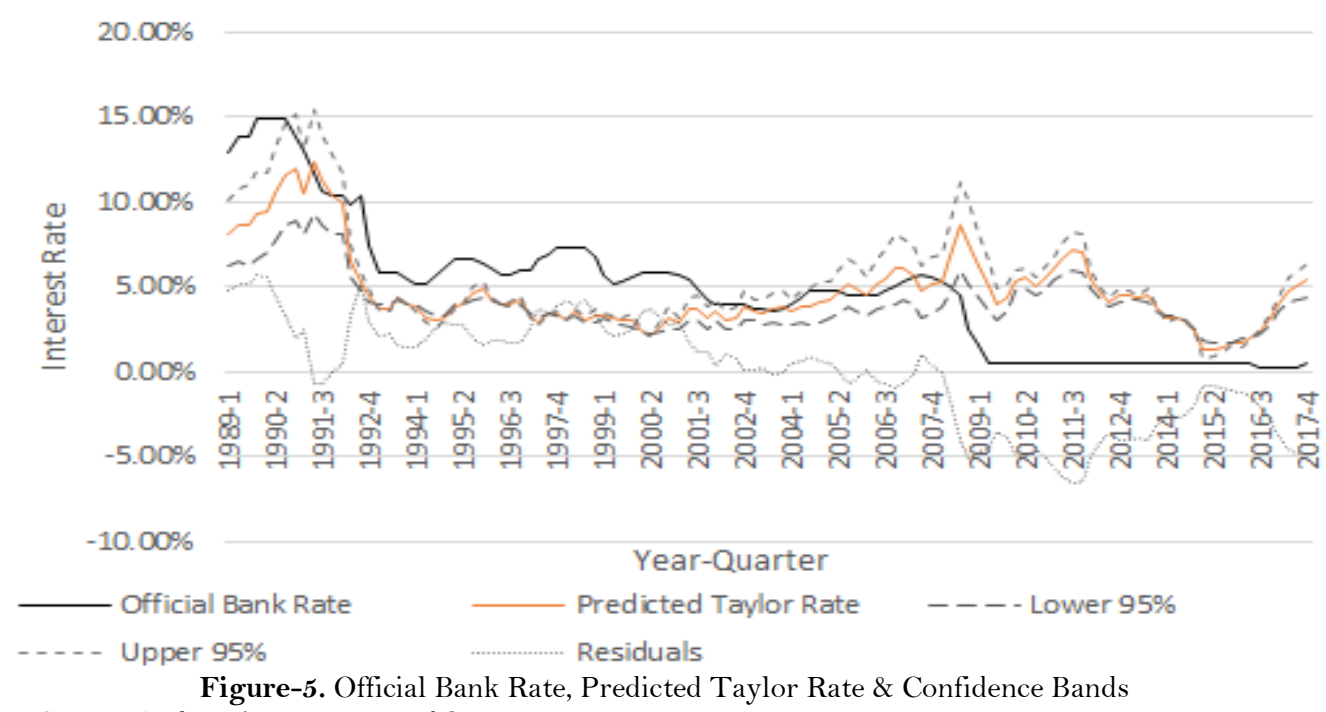

Source: Authors' interest rate model.

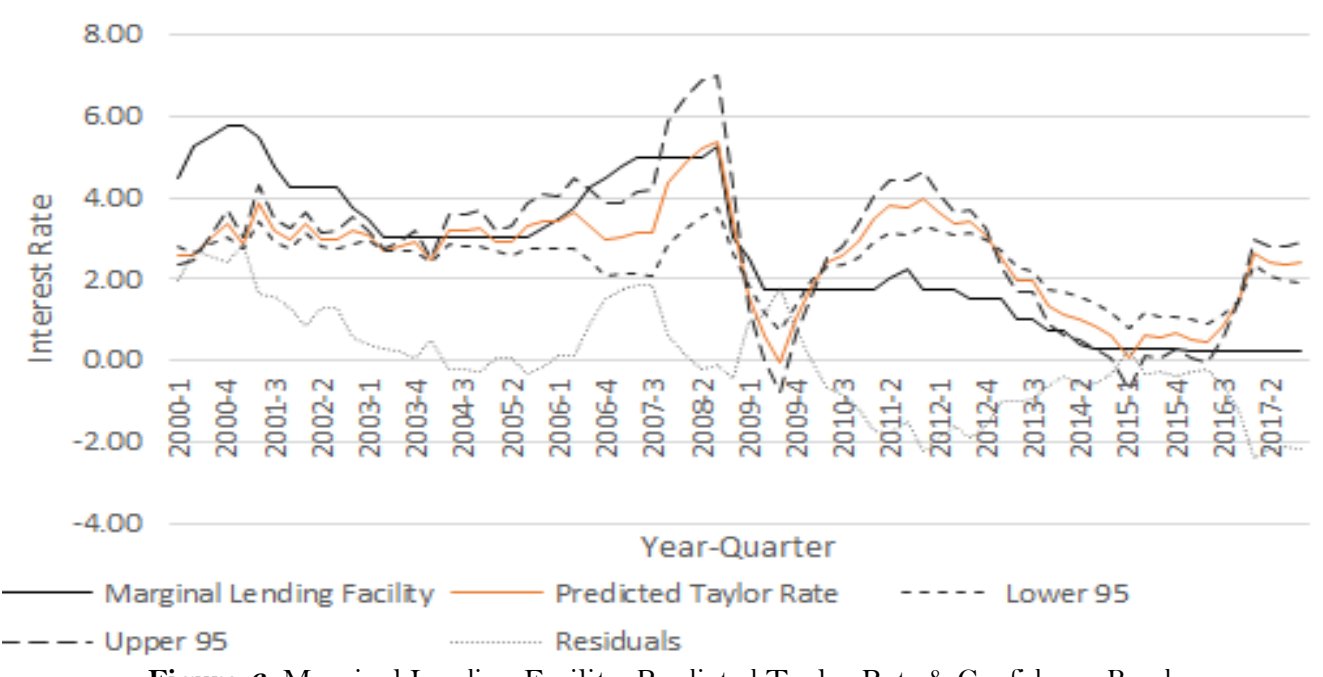

Figure-6. Marginal Lendi
Source: Authors' interest rate model. 

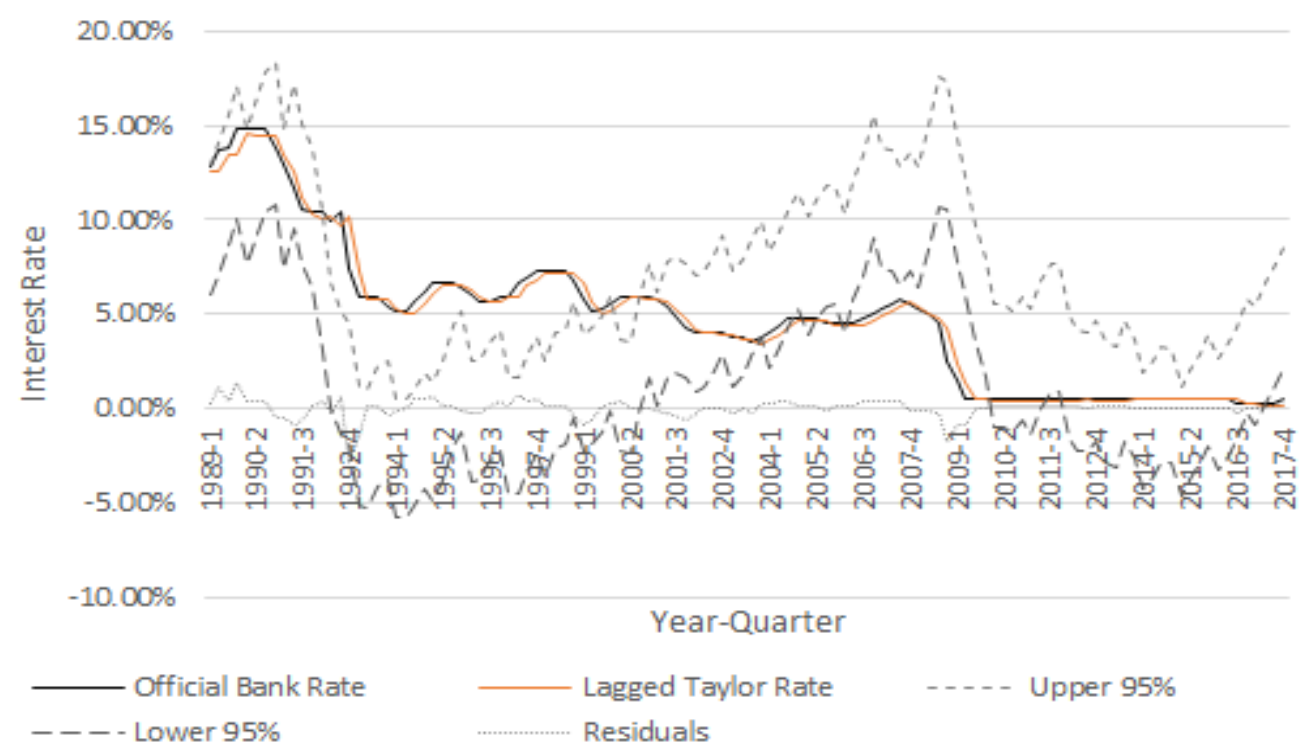

Figure-7. Official Bank Rate, Lagged Taylor Rate and Confidence Bands Source: Authors' interest rate model.

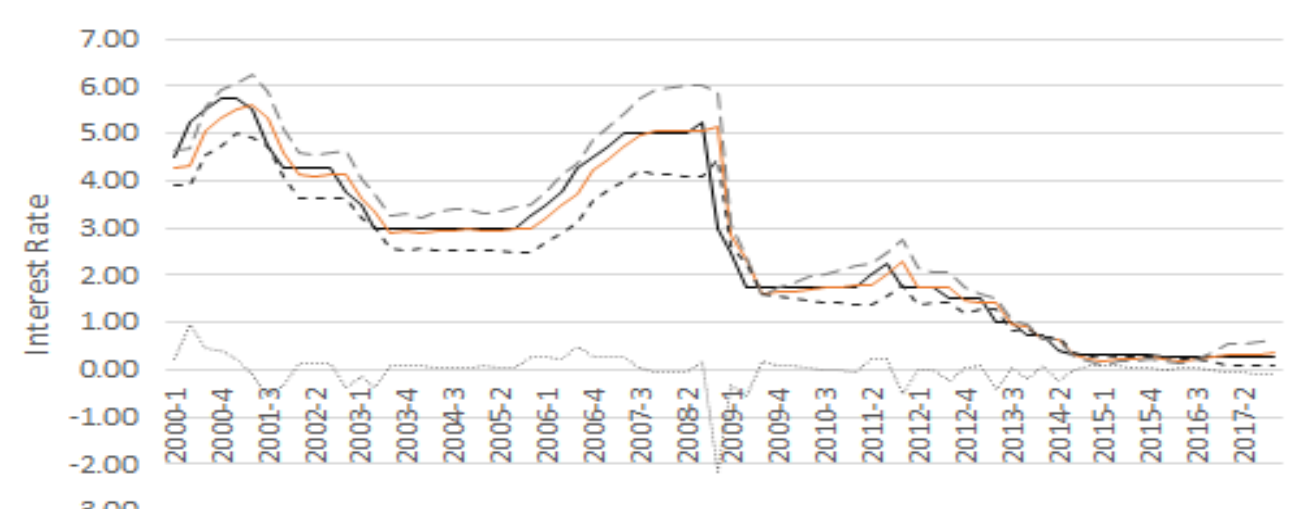

Year-Quarter

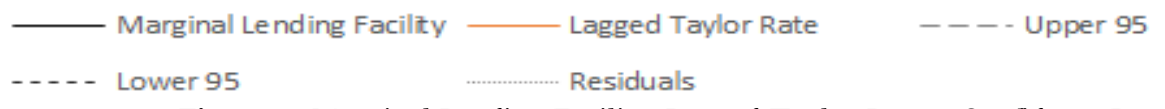

Figure-8. Marginal Lending Facility, Lagged Taylor Rate \& Confidence Band Source: Authors' interest rate model.

The coefficients of the inflation gap were similar for both the Bank of England and the European Central Bank, which shows the central banks place a similar emphasis on the inflation gap when setting interest rates. When the inflation gap rose by one, both central banks respond by increasing the interest rate by more than one. Like Bhattarai (2008) we also find that the interest rate for the United Kingdom is more responsive to the inflation gap than the output gap.

The results from the estimation of the second model that attempts to account for interest rate smoothing returned the following interest rate rule for the United Kingdom (3) and Euro area (4):

$$
\begin{aligned}
& \mathrm{i}_{\mathrm{t}}=-0.0004-0.05\left(\mathrm{Y}_{\mathrm{t}}-\mathrm{Y}_{\mathrm{t}}^{*}\right)-0.004\left(\pi_{\mathrm{t}}-\pi_{\mathrm{t}}^{*}\right)+0.99 \mathrm{i}_{\mathrm{t}-1}
\end{aligned}
$$

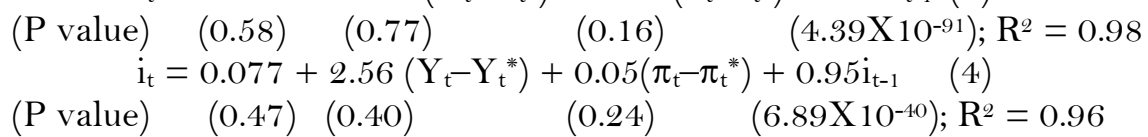

The estimated rule for both the United Kingdom $\left(\mathrm{R}^{2}=0.98\right)$ and Euro area $\left(\mathrm{R}^{2}=0.96\right)$ had a strong fit to the data. Despite this, the output gap and inflation gap in both equations are statistically insignificant. Moreover, the output gap and inflation gap in equation 3 have a negative coefficient which does not make economic sense; the interest rate should rise with the inflation gap and output gap, not fall (Bhattarai, 2018).

The results are similar to those of Coibion and Yuriy (2011) who found that the "coefficients on lagged interest rate are around 0.90 and are statistically significant at conventional levels". The significance of the lagged interest rate and insignificance of both the output gap and inflation gap in equations 3 and 4 suggest that both the Bank of England and European Central Bank smooth interest rates.

The original Taylor rule poorly forecasts both the Official Bank Rate and the Marginal Lending Facility in the period analysed as shown in Figures 5 and 6 . The accuracy of the forecasts were significantly improved when accounting for interest rate smoothing as shown in Figures 7 and 8.

Over the period analysed, the Taylor rate is a lot more volatile in comparison to the Bank Rate and the Marginal Lending Facility which is comparable to the results of Coibion and Yuriy (2011). Unlike the interest rates set by central banks, the Taylor rule advocates for interest rate changes in each of the periods analysed. This emphasises (Taylor, 1993) point that it would be unrealistic for monetary policy to strictly adhere to the Taylor rule as it would not be reasonable for a central bank to frequently change interest rates.

The Taylor rules estimated do not predict negative interest rates over the period analysed for either the United Kingdom or the Euro area. Thus, like Nikolsko-Rzhevskyy and Papell (2012) our results do not provide the rationale for quantitative easing in the years following the financial crisis. Despite this, both the Bank of England and European Central Bank engaged in large asset repurchase programs following the financial crisis. Several economists have argued that this, coupled with an extended period of zero interest rate policy, lead to the 
formation of asset bubbles within the economy. However, this would require further exploration which is outside the scope of this paper.

\section{Conclusion}

The results show that the original Taylor rule poorly explains monetary policy in both the United Kingdom and Euro area. The addition of a one-period lagged interest rate significantly improved the fit of the model to the data, suggesting that central banks smooth interest rates over time. The forecasted Taylor rates show that the Bank of England's and European Central Banks monetary policy was too loose leading up to and following the financial crisis. Moreover, the forecasted rates to not prescribe the rationale for quantitative easing in either region.

In conclusion, the Taylor rule continues to be a useful tool for both academics and policymakers alike. The volatility of the Taylor rule emphasises (Taylor, 1993) point that policymakers should use the rule as a guideline and not strictly adhere to it. Nevertheless, the rule has some important implications for how central banks conduct monetary policy in the future.

\section{References}

Alcidi, C., M. Busse and D. Gros, 2016. Is there a need for additional monetary stimulus? Insights from the original Taylor Rule. No. 11492. Centre for European Policy Studies, 2016.

Bank of England, 2018. The interest rate. Official Bank Rate Historical Data. Available from https://www.bankofengland.co.uk/monetarypolicy/the-interest-rate-bank-rate [Accessed 06/01/2018].

Bhattarai, 2018. Advanced macroeconomics. UK: University of Hull.

Bhattarai, K., 2008. An empirical study of interest rate determination rules. Applied Financial Economics, 18(4): 327-343. Available at: https://doi.org/10.1080/09603100500447560.

Castro, V., 2008. Are central banks following a linear or nonlinear (augmented) Taylor rule? (No. 19/2008). NIPE-Universidade do Minho.

Coibion, O. and G. Yuriy, 2011. Why are target interest rate changes so persistent? NBER Working Papers 16707, National Bureau of Economic Research, Inc.

Cukierman, A. and V. Muscatelli, 2008. Nonlinear taylor rules and asymmetric preferences in central banking: Evidence from the United Kingdom and the United States. The BE Journal of Macroeconomics, 8(1): 1-31. Available at: https://doi.org/10.2202/19351690.1488

Driffill, E. and Z. Rotondi, 2007. Inertia in Taylor Rules (No. 0720). Birkbeck, Department of Economics, Mathematics \& Statistics.

ECB Statistical Data Warehouse, 2018. Inflation rate (HICP). Available from http://sdw.ecb.europa.eu/[Accessed 13/04/2018].

Federal Reserve Economic Data, 2018. Euro Area Interest Rate. Available from https://fred.stlouisfed.org/series/INTDSREZQ193N [Accessed 19/03/2018].

Filardo, A. and J. Nakajima, 2018. Effectiveness of Unconventional Monetary Policies in a Low Interest Rate Environment (BIS Working Papers No 691).

FRED, 2018. Euro Area GDP. Available from https://fred.stlouisfed.org/series/CLVMEURSCAB1GQEA19 [Accessed 19/03/2018]

González-Páramo, J., 2005. The European Central Bank's monetary policy in an international context: Principles and challenges. Available from https://www.ecb.europa.eu/press/key/date/2005/html/sp050623.en.html [Accessed 23/03/2017].

Haug, S. and M. Nesse, 2016. Taylor rules and monetary policy in the Eurozone. Master's Thesis. Norwegian School of Economics.

Kulikauskas, D., 2014. Nonlinear taylor rule for the European Central Bank. Economics Bulletin, 34(3): 1798-1804.

Lee, K., N. Olekalns and K. Shields, 2013. Meta Taylor rules for the UK and Australia; Accommodating regime uncertainty in monetary policy analysis using model averaging methods. The Manchester School, 3(81): 28-53. Available at: https://doi.org/10.1111/manc.12000.

Loide, G., 2014. The Taylor rule as a benchmark for ECB interest rate setting. Master's Thesis. Tallinn School of Economics and Business Administration.

Maza, A. and B. Sanchez-Robles, 2013. The European central Bank monetary policy and the taylor rule, 1999-2009 the monetary policy of the Central European Bank and the rule of taylor, 1999-2009. World Economic Review, 32: 179-193.

Nikolsko-Rzhevskyy, A. and D. Papell, 2012. Taylor's rule versus Taylor rules. International Finance, 16(1): 71-93.

Office of National Statistics, 2018. Gross domestic product. GDP: Chained volume measures: Seasonally adjusted £m. Available from https://www.ons.gov.uk/economy/grossdomesticproductgdp [Accessed 06/01/2018].

ONS, 2016. Chain-linking methods used within the UK National Accounts. Available from https://www.ons.gov.uk/economy/nationalaccounts/uksectoraccounts/methodologies/chainlinkingmethodsusedwithintheuknatio nalaccounts [Accessed 07/01/2018].

ONS, 2018. Inflation and price indices. CPIH Annual Rate. Available from https://www.ons.gov.uk/economy/inflationandpriceindices [Accessed 06/01/2018].

Taylor, J., 1993. Discretion versus policy rules in practice. Carnegie-Rochester Conference Series on Public Policy, 39: 195-2 14.

Taylor, M.P. and E. Davradakis, 2006. Interest rate setting and inflation targeting: Evidence of a nonlinear Taylor rule for the United Kingdom. Studies in Nonlinear Dynamics \& Econometrics, 1O(4): 1-20. Available at: https://doi.org/10.2202/1558-3708.1359.

Woodford, M., 2001. The Taylor rule and optimal monetary policy. American Economic Review, 91(2): 232-237. Available at: https://doi.org/10.1257/aer.91.2.232. 


\section{Appendices}

Appendix 1 - Data Used

United Kingdom

\begin{tabular}{|c|c|c|c|c|c|c|}
\hline Year & $\begin{array}{l}\text { Official } \\
\text { Bank Rate }\end{array}$ & $\begin{array}{l}\text { Lagged Bank } \\
\text { Rate }\end{array}$ & $\begin{array}{l}\text { Inflation } \\
\text { Gap }\end{array}$ & Output Gap & $\begin{array}{l}\text { Taylor } \\
\text { Rate }\end{array}$ & $\begin{array}{l}\text { Lagged } \\
\text { Taylor Rate }\end{array}$ \\
\hline 1989-1 & $12.88 \%$ & $12.88 \%$ & $3.00 \%$ & 0.02041386 & $8.14 \%$ & $12.59 \%$ \\
\hline 1989-2 & $13.75 \%$ & $12.88 \%$ & $3.30 \%$ & 0.02637319 & $8.61 \%$ & $12.57 \%$ \\
\hline 1989-3 & $13.81 \%$ & $13.75 \%$ & $3.10 \%$ & 0.04155653 & $8.60 \%$ & $13.44 \%$ \\
\hline 1989-4 & $14.88 \%$ & $13.81 \%$ & $3.50 \%$ & 0.05014553 & $9.24 \%$ & $13.48 \%$ \\
\hline 1990-1 & $14.88 \%$ & $14.88 \%$ & $3.90 \%$ & 0.02616712 & $9.35 \%$ & $14.53 \%$ \\
\hline $1990-2$ & $14.88 \%$ & $14.88 \%$ & $4.70 \%$ & 0.03265785 & $10.45 \%$ & $14.49 \%$ \\
\hline $1990-3$ & $14.88 \%$ & $14.88 \%$ & $5.60 \%$ & 0.03361574 & $11.58 \%$ & $14.45 \%$ \\
\hline $1990-4$ & $13.88 \%$ & $14.88 \%$ & $5.90 \%$ & 0.03452015 & $11.97 \%$ & $14.43 \%$ \\
\hline 1991-1 & $13.00 \%$ & $13.88 \%$ & $5.00 \%$ & 0.01369227 & $10.52 \%$ & $13.49 \%$ \\
\hline $1991-2$ & $11.63 \%$ & $13.00 \%$ & $6.40 \%$ & 0.01882321 & $12.34 \%$ & $12.55 \%$ \\
\hline 1991-3 & $10.61 \%$ & $11.63 \%$ & $5.70 \%$ & 0.00838792 & $11.30 \%$ & $11.23 \%$ \\
\hline 1991-4 & $10.38 \%$ & $10.61 \%$ & $5.00 \%$ & 0.00504432 & $10.38 \%$ & $10.25 \%$ \\
\hline 1992-1 & $10.38 \%$ & $10.38 \%$ & $5.00 \%$ & -0.0245736 & $9.90 \%$ & $10.03 \%$ \\
\hline 1992-2 & $9.88 \%$ & $10.38 \%$ & $2.30 \%$ & -0.0257854 & $6.52 \%$ & $10.16 \%$ \\
\hline 1992-3 & $10.38 \%$ & $9.88 \%$ & $1.30 \%$ & -0.0280686 & $5.24 \%$ & $9.71 \%$ \\
\hline $1992-4$ & $7.38 \%$ & $10.38 \%$ & $0.70 \%$ & -0.0264659 & $4.52 \%$ & $10.23 \%$ \\
\hline $1993-1$ & $5.88 \%$ & $7.38 \%$ & $0.40 \%$ & -0.0526212 & $3.73 \%$ & $7.28 \%$ \\
\hline 1993-2 & $5.88 \%$ & $5.88 \%$ & $0.40 \%$ & -0.0538531 & $3.71 \%$ & $5.79 \%$ \\
\hline 1993-3 & $5.88 \%$ & $5.88 \%$ & $0.80 \%$ & -0.0474738 & $4.31 \%$ & $5.77 \%$ \\
\hline $1993-4$ & $5.38 \%$ & $5.88 \%$ & $0.40 \%$ & -0.0404622 & $3.92 \%$ & $5.79 \%$ \\
\hline 1994-1 & $5.13 \%$ & $5.38 \%$ & $0.50 \%$ & -0.0586057 & $3.76 \%$ & $5.29 \%$ \\
\hline 1994-2 & $5.13 \%$ & $5.13 \%$ & $0.00 \%$ & -0.0535331 & $3.21 \%$ & $5.07 \%$ \\
\hline 1994-3 & $5.63 \%$ & $5.13 \%$ & $-0.30 \%$ & -0.0455212 & $2.97 \%$ & $5.08 \%$ \\
\hline 1994-4 & $6.13 \%$ & $5.63 \%$ & $-0.20 \%$ & -0.0387289 & $3.20 \%$ & $5.57 \%$ \\
\hline 1995-1 & $6.63 \%$ & $6.13 \%$ & $0.50 \%$ & -0.0515787 & $3.87 \%$ & $6.03 \%$ \\
\hline $1995-2$ & $6.63 \%$ & $6.63 \%$ & $0.40 \%$ & -0.0400405 & $3.93 \%$ & $6.53 \%$ \\
\hline 1995-3 & $6.63 \%$ & $6.63 \%$ & $0.80 \%$ & -0.0287551 & $4.61 \%$ & $6.51 \%$ \\
\hline $1995-4$ & $6.38 \%$ & $6.63 \%$ & $0.90 \%$ & -0.0230882 & $4.82 \%$ & $6.50 \%$ \\
\hline 1996-1 & $6.03 \%$ & $6.38 \%$ & $0.70 \%$ & -0.0439461 & $4.24 \%$ & $6.27 \%$ \\
\hline 1996-2 & $5.69 \%$ & $6.03 \%$ & $0.40 \%$ & -0.0403429 & $3.92 \%$ & $5.94 \%$ \\
\hline 1996-3 & $5.69 \%$ & $5.69 \%$ & $0.30 \%$ & -0.0305549 & $3.96 \%$ & $5.60 \%$ \\
\hline $1996-4$ & $5.94 \%$ & $5.69 \%$ & $0.50 \%$ & -0.0276956 & $4.25 \%$ & $5.59 \%$ \\
\hline $1997-1$ & $5.94 \%$ & $5.94 \%$ & $-0.10 \%$ & -0.042282 & $3.27 \%$ & $5.87 \%$ \\
\hline $1997-2$ & $6.63 \%$ & $5.94 \%$ & $-0.40 \%$ & -0.0391345 & $2.95 \%$ & $5.89 \%$ \\
\hline 1997-3 & $6.88 \%$ & $6.63 \%$ & $-0.10 \%$ & -0.0323802 & $3.43 \%$ & $6.55 \%$ \\
\hline $1997-4$ & $7.25 \%$ & $6.88 \%$ & $-0.20 \%$ & -0.023007 & $3.46 \%$ & $6.80 \%$ \\
\hline 1998-1 & $7.25 \%$ & $7.25 \%$ & $-0.40 \%$ & -0.0317384 & $3.07 \%$ & $7.18 \%$ \\
\hline $1998-2$ & $7.25 \%$ & $7.25 \%$ & $-0.20 \%$ & -0.021078 & $3.49 \%$ & $7.17 \%$ \\
\hline 1998-3 & $7.25 \%$ & $7.25 \%$ & $-0.60 \%$ & -0.0151367 & $3.08 \%$ & $7.19 \%$ \\
\hline $1998-4$ & $6.75 \%$ & $7.25 \%$ & $-0.60 \%$ & -0.0029516 & $3.28 \%$ & $7.18 \%$ \\
\hline 1999-1 & $5.75 \%$ & $6.75 \%$ & $-0.40 \%$ & -0.0199983 & $3.26 \%$ & $6.68 \%$ \\
\hline 1999-2 & $5.13 \%$ & $5.75 \%$ & $-0.60 \%$ & -0.0141542 & $3.10 \%$ & $5.70 \%$ \\
\hline 1999-3 & $5.25 \%$ & $5.13 \%$ & $-0.80 \%$ & -0.0068663 & $2.97 \%$ & $5.08 \%$ \\
\hline 1999-4 & $5.50 \%$ & $5.25 \%$ & $-0.90 \%$ & 0.00349916 & $3.01 \%$ & $5.21 \%$ \\
\hline 2000-1 & $5.88 \%$ & $5.50 \%$ & $-1.20 \%$ & -0.0125693 & $2.38 \%$ & $5.48 \%$ \\
\hline $2000-2$ & $5.88 \%$ & $5.88 \%$ & $-1.40 \%$ & -0.0118747 & $2.14 \%$ & $5.86 \%$ \\
\hline 2000-3 & $5.88 \%$ & $5.88 \%$ & $-1.20 \%$ & 0.00551846 & $2.67 \%$ & $5.84 \%$ \\
\hline $2000-4$ & $5.88 \%$ & $5.88 \%$ & $-1.00 \%$ & 0.01957437 & $3.14 \%$ & $5.83 \%$ \\
\hline 2001-1 & $5.75 \%$ & $5.88 \%$ & $-1.10 \%$ & 0.00726313 & $2.82 \%$ & $5.84 \%$ \\
\hline $2001-2$ & $5.38 \%$ & $5.75 \%$ & $-0.50 \%$ & 0.01442447 & $3.68 \%$ & $5.68 \%$ \\
\hline 2001-3 & $4.88 \%$ & $5.38 \%$ & $-0.50 \%$ & 0.01738216 & $3.73 \%$ & $5.31 \%$ \\
\hline $2001-4$ & $4.25 \%$ & $4.88 \%$ & $-1.00 \%$ & 0.01947702 & $3.14 \%$ & $4.83 \%$ \\
\hline 2002-1 & $4.00 \%$ & $4.25 \%$ & $-0.50 \%$ & 0.00840409 & $3.59 \%$ & $4.19 \%$ \\
\hline $2002-2$ & $4.00 \%$ & $4.00 \%$ & $-1.10 \%$ & 0.01664342 & $2.97 \%$ & $3.97 \%$ \\
\hline $2002-3$ & $4.00 \%$ & $4.00 \%$ & $-1.00 \%$ & 0.02305946 & $3.20 \%$ & $3.96 \%$ \\
\hline $2002-4$ & $4.00 \%$ & $4.00 \%$ & $-0.50 \%$ & 0.0263434 & $3.87 \%$ & $3.94 \%$ \\
\hline 2003-1 & $3.75 \%$ & $4.00 \%$ & $-0.50 \%$ & 0.01045874 & $3.62 \%$ & $3.95 \%$ \\
\hline 2003-2 & $3.75 \%$ & $3.75 \%$ & $-0.70 \%$ & 0.01760398 & $3.49 \%$ & $3.70 \%$ \\
\hline
\end{tabular}




\begin{tabular}{|c|c|c|c|c|c|c|}
\hline 2003-3 & $3.50 \%$ & $3.75 \%$ & $-0.60 \%$ & 0.02562235 & $3.74 \%$ & $3.70 \%$ \\
\hline 2003-4 & $3.75 \%$ & $3.50 \%$ & $-0.70 \%$ & 0.03502976 & $3.77 \%$ & $3.45 \%$ \\
\hline 2004-1 & $4.00 \%$ & $3.75 \%$ & $-0.70 \%$ & 0.02094635 & $3.54 \%$ & $3.70 \%$ \\
\hline 2004-2 & $4.38 \%$ & $4.00 \%$ & $-0.60 \%$ & 0.02996588 & $3.81 \%$ & $3.94 \%$ \\
\hline 2004-3 & $4.75 \%$ & $4.38 \%$ & $-0.70 \%$ & 0.03989003 & $3.84 \%$ & $4.32 \%$ \\
\hline 2004-4 & $4.75 \%$ & $4.75 \%$ & $-0.60 \%$ & 0.0476402 & $4.09 \%$ & $4.68 \%$ \\
\hline 2005-1 & $4.75 \%$ & $4.75 \%$ & $-0.30 \%$ & 0.03293418 & $4.23 \%$ & $4.67 \%$ \\
\hline 2005-2 & $4.75 \%$ & $4.75 \%$ & $0.00 \%$ & 0.0371452 & $4.67 \%$ & $4.66 \%$ \\
\hline 2005-3 & $4.50 \%$ & $4.75 \%$ & $0.40 \%$ & 0.03944807 & $5.21 \%$ & $4.64 \%$ \\
\hline $2005-4$ & $4.50 \%$ & $4.50 \%$ & $0.10 \%$ & 0.04307123 & $4.89 \%$ & $4.40 \%$ \\
\hline $2006-1$ & $4.50 \%$ & $4.50 \%$ & $-0.10 \%$ & 0.03201837 & $4.46 \%$ & $4.41 \%$ \\
\hline 2006-2 & $4.50 \%$ & $4.50 \%$ & $0.30 \%$ & 0.04289975 & $5.14 \%$ & $4.39 \%$ \\
\hline 2006-3 & $4.75 \%$ & $4.50 \%$ & $0.40 \%$ & 0.05340497 & $5.43 \%$ & $4.38 \%$ \\
\hline $2006-4$ & $5.00 \%$ & $4.75 \%$ & $0.70 \%$ & 0.06796726 & $6.04 \%$ & $4.61 \%$ \\
\hline $2007-1$ & $5.25 \%$ & $5.00 \%$ & $0.90 \%$ & 0.0514821 & $6.02 \%$ & $4.86 \%$ \\
\hline $2007-2$ & $5.50 \%$ & $5.25 \%$ & $0.60 \%$ & 0.0535055 & $5.68 \%$ & $5.12 \%$ \\
\hline 2007-3 & $5.75 \%$ & $5.50 \%$ & $-0.20 \%$ & 0.05429788 & $4.70 \%$ & $5.40 \%$ \\
\hline $2007-4$ & $5.50 \%$ & $5.75 \%$ & $0.10 \%$ & 0.05793939 & $5.13 \%$ & $5.63 \%$ \\
\hline 2008-1 & $5.25 \%$ & $5.50 \%$ & $0.40 \%$ & 0.04816291 & $5.35 \%$ & $5.38 \%$ \\
\hline $2008-2$ & $5.00 \%$ & $5.25 \%$ & $1.40 \%$ & 0.05529619 & $6.70 \%$ & $5.08 \%$ \\
\hline 2008-3 & $4.50 \%$ & $5.00 \%$ & $2.80 \%$ & 0.06189576 & $8.55 \%$ & $4.76 \%$ \\
\hline $2008-4$ & $2.50 \%$ & $4.50 \%$ & $1.90 \%$ & 0.0699027 & $7.56 \%$ & $4.31 \%$ \\
\hline 2009-1 & $1.50 \%$ & $2.50 \%$ & $1.00 \%$ & 0.05420973 & $6.19 \%$ & $2.37 \%$ \\
\hline 2009-2 & $0.50 \%$ & $1.50 \%$ & $0.10 \%$ & 0.04742543 & $4.96 \%$ & $1.42 \%$ \\
\hline 2009-3 & $0.50 \%$ & $0.50 \%$ & $-0.50 \%$ & 0.03128546 & $3.95 \%$ & $0.46 \%$ \\
\hline 2009-4 & $0.50 \%$ & $0.50 \%$ & $0.10 \%$ & 0.00928011 & $4.35 \%$ & $0.44 \%$ \\
\hline 2010-1 & $0.50 \%$ & $0.50 \%$ & $1.30 \%$ & -0.0249093 & $5.29 \%$ & $0.40 \%$ \\
\hline $2010-2$ & $0.50 \%$ & $0.50 \%$ & $1.50 \%$ & -0.0271643 & $5.51 \%$ & $0.39 \%$ \\
\hline $2010-3$ & $0.50 \%$ & $0.50 \%$ & $1.10 \%$ & -0.0256135 & $5.03 \%$ & $0.41 \%$ \\
\hline $2010-4$ & $0.50 \%$ & $0.50 \%$ & $1.40 \%$ & -0.0229499 & $5.45 \%$ & $0.40 \%$ \\
\hline $2011-1$ & $0.50 \%$ & $0.50 \%$ & $2.10 \%$ & -0.0353414 & $6.12 \%$ & $0.37 \%$ \\
\hline $2011-2$ & $0.50 \%$ & $0.50 \%$ & $2.40 \%$ & -0.0263831 & $6.64 \%$ & $0.35 \%$ \\
\hline $2011-3$ & $0.50 \%$ & $0.50 \%$ & $2.70 \%$ & -0.0217527 & $7.09 \%$ & $0.34 \%$ \\
\hline $2011-4$ & $0.50 \%$ & $0.50 \%$ & $2.60 \%$ & -0.0210309 & $6.97 \%$ & $0.34 \%$ \\
\hline $2012-1$ & $0.50 \%$ & $0.50 \%$ & $1.50 \%$ & -0.0326248 & $5.42 \%$ & $0.40 \%$ \\
\hline $2012-2$ & $0.50 \%$ & $0.50 \%$ & $0.80 \%$ & -0.0311448 & $4.57 \%$ & $0.43 \%$ \\
\hline 2012-3 & $0.50 \%$ & $0.50 \%$ & $0.40 \%$ & -0.027346 & $4.13 \%$ & $0.45 \%$ \\
\hline $2012-4$ & $0.50 \%$ & $0.50 \%$ & $0.70 \%$ & -0.0254473 & $4.54 \%$ & $0.43 \%$ \\
\hline 2013-1 & $0.50 \%$ & $0.50 \%$ & $0.80 \%$ & -0.036151 & $4.49 \%$ & $0.43 \%$ \\
\hline 2013-2 & $0.50 \%$ & $0.50 \%$ & $0.70 \%$ & -0.0372187 & $4.35 \%$ & $0.44 \%$ \\
\hline 2013-3 & $0.50 \%$ & $0.50 \%$ & $0.70 \%$ & -0.0257741 & $4.53 \%$ & $0.43 \%$ \\
\hline 2013-4 & $0.50 \%$ & $0.50 \%$ & $0.10 \%$ & -0.0272256 & $3.76 \%$ & $0.46 \%$ \\
\hline 2014-1 & $0.50 \%$ & $0.50 \%$ & $-0.30 \%$ & -0.0377201 & $3.09 \%$ & $0.48 \%$ \\
\hline 2014-2 & $0.50 \%$ & $0.50 \%$ & $-0.30 \%$ & -0.0323288 & $3.18 \%$ & $0.48 \%$ \\
\hline 2014-3 & $0.50 \%$ & $0.50 \%$ & $-0.50 \%$ & -0.0238611 & $3.07 \%$ & $0.49 \%$ \\
\hline $2014-4$ & $0.50 \%$ & $0.50 \%$ & $-1.10 \%$ & -0.0186855 & $2.40 \%$ & $0.51 \%$ \\
\hline 2015-1 & $0.50 \%$ & $0.50 \%$ & $-1.90 \%$ & -0.0267115 & $1.28 \%$ & $0.55 \%$ \\
\hline $2015-2$ & $0.50 \%$ & $0.50 \%$ & $-2.00 \%$ & -0.0182179 & $1.29 \%$ & $0.55 \%$ \\
\hline 2015-3 & $0.50 \%$ & $0.50 \%$ & $-2.00 \%$ & -0.0106353 & $1.41 \%$ & $0.55 \%$ \\
\hline $2015-4$ & $0.50 \%$ & $0.50 \%$ & $-1.90 \%$ & -0.0030519 & $1.66 \%$ & $0.54 \%$ \\
\hline 2016-1 & $0.50 \%$ & $0.50 \%$ & $-1.70 \%$ & -0.0159405 & $1.70 \%$ & $0.54 \%$ \\
\hline $2016-2$ & $0.50 \%$ & $0.50 \%$ & $-1.60 \%$ & -0.0102088 & $1.92 \%$ & $0.53 \%$ \\
\hline 2016-3 & $0.25 \%$ & $0.50 \%$ & $-1.30 \%$ & -0.006052 & $2.36 \%$ & $0.52 \%$ \\
\hline $2016-4$ & $0.25 \%$ & $0.25 \%$ & $-0.80 \%$ & 0.00117998 & $3.10 \%$ & $0.24 \%$ \\
\hline $2017-1$ & $0.25 \%$ & $0.25 \%$ & $0.10 \%$ & -0.0127535 & $3.99 \%$ & $0.21 \%$ \\
\hline $2017-2$ & $0.25 \%$ & $0.25 \%$ & $0.70 \%$ & -0.0080059 & $4.82 \%$ & $0.18 \%$ \\
\hline $2017-3$ & $0.25 \%$ & $0.25 \%$ & $0.80 \%$ & -0.0026108 & $5.03 \%$ & $0.17 \%$ \\
\hline $2017-4$ & $0.50 \%$ & $0.25 \%$ & $1.00 \%$ & 0.00484444 & $5.40 \%$ & $0.16 \%$ \\
\hline
\end{tabular}


Euro Area

\begin{tabular}{|c|c|c|c|c|c|c|}
\hline Year & $\begin{array}{l}\text { Marginal } \\
\text { Lending Facility }\end{array}$ & $\begin{array}{l}\text { Lagged } \\
\text { MLF }\end{array}$ & $\begin{array}{l}\text { Inflation } \\
\text { Gap } \\
\end{array}$ & $\begin{array}{l}\text { Output } \\
\text { Gap }\end{array}$ & $\begin{array}{l}\text { Taylor } \\
\text { Rate }\end{array}$ & $\begin{array}{l}\text { Lagged } \\
\text { Taylor Rate } \\
\end{array}$ \\
\hline 2000-1 & 4.50 & 4.50 & -0.07 & -0.03 & 3.36 & 4.29 \\
\hline $2000-2$ & 5.25 & 4.50 & -0.13 & -0.02 & 3.46 & 4.32 \\
\hline 2000-3 & 5.50 & 5.25 & 0.17 & -0.02 & 3.53 & 5.04 \\
\hline $2000-4$ & 5.75 & 5.50 & 0.47 & -0.01 & 3.59 & 5.30 \\
\hline 2001-1 & 5.75 & 5.75 & 0.07 & -0.01 & 3.56 & 5.53 \\
\hline 2001-2 & 5.50 & 5.75 & 0.90 & -0.01 & 3.54 & 5.54 \\
\hline 2001-3 & 4.75 & 5.50 & 0.33 & -0.01 & 3.49 & 5.30 \\
\hline $2001-4$ & 4.25 & 4.75 & 0.13 & -0.01 & 3.44 & 4.59 \\
\hline 2002-1 & 4.25 & 4.25 & 0.53 & -0.02 & 3.24 & 4.09 \\
\hline 2002-2 & 4.25 & 4.25 & 0.13 & -0.01 & 3.19 & 4.10 \\
\hline $2002-3$ & 4.25 & 4.25 & 0.10 & -0.01 & 3.14 & 4.11 \\
\hline $2002-4$ & 3.75 & 4.25 & 0.30 & -0.01 & 3.06 & 4.11 \\
\hline 2003-1 & 3.50 & 3.75 & 0.30 & -0.02 & 2.79 & 3.59 \\
\hline 2003-2 & 3.00 & 3.50 & -0.03 & -0.02 & 2.73 & 3.36 \\
\hline 2003-3 & 3.00 & 3.00 & 0.00 & -0.01 & 2.74 & 2.90 \\
\hline 2003-4 & 3.00 & 3.00 & 0.07 & -0.01 & 2.80 & 2.92 \\
\hline 2004-1 & 3.00 & 3.00 & -0.30 & -0.01 & 2.85 & 2.91 \\
\hline 2004-2 & 3.00 & 3.00 & 0.30 & 0.00 & 2.93 & 2.93 \\
\hline 2004-3 & 3.00 & 3.00 & 0.27 & 0.00 & 3.00 & 2.94 \\
\hline 2004-4 & 3.00 & 3.00 & 0.30 & 0.00 & 3.09 & 2.95 \\
\hline 2005-1 & 3.00 & 3.00 & 0.07 & -0.01 & 3.14 & 2.93 \\
\hline $2005-2$ & 3.00 & 3.00 & 0.03 & 0.00 & 3.26 & 2.95 \\
\hline 2005-3 & 3.00 & 3.00 & 0.30 & 0.01 & 3.37 & 2.98 \\
\hline $2005-4$ & 3.25 & 3.00 & 0.33 & 0.01 & 3.48 & 3.00 \\
\hline 2006-1 & 3.50 & 3.25 & 0.33 & 0.01 & 3.56 & 3.24 \\
\hline $2006-2$ & 3.75 & 3.50 & 0.47 & 0.02 & 3.67 & 3.50 \\
\hline 2006-3 & 4.25 & 3.75 & 0.17 & 0.03 & 3.73 & 3.76 \\
\hline 2006-4 & 4.50 & 4.25 & -0.20 & 0.04 & 3.80 & 4.26 \\
\hline 2007-1 & 4.75 & 4.50 & -0.17 & 0.04 & 3.39 & 4.48 \\
\hline $2007-2$ & 5.00 & 4.75 & -0.10 & 0.05 & 3.51 & 4.73 \\
\hline $2007-3$ & 5.00 & 5.00 & -0.13 & 0.05 & 3.74 & 4.99 \\
\hline $2007-4$ & 5.00 & 5.00 & 0.90 & 0.06 & 4.08 & 5.02 \\
\hline 2008-1 & 5.00 & 5.00 & 1.37 & 0.05 & 5.61 & 5.08 \\
\hline 2008-2 & 5.00 & 5.00 & 1.67 & 0.05 & 5.64 & 5.07 \\
\hline 2008-3 & 5.25 & 5.00 & 1.83 & 0.04 & 5.32 & 5.04 \\
\hline $2008-4$ & 3.00 & 5.25 & 0.30 & 0.02 & 4.55 & 5.20 \\
\hline 2009-1 & 2.50 & 3.00 & -1.03 & -0.01 & 1.59 & 2.84 \\
\hline 2009-2 & 1.75 & 2.50 & -1.83 & -0.02 & 0.91 & 2.33 \\
\hline 2009-3 & 1.75 & 1.75 & -2.40 & -0.01 & 0.60 & 1.62 \\
\hline 2009-4 & 1.75 & 1.75 & -1.57 & -0.01 & 0.63 & 1.63 \\
\hline $2010-1$ & 1.75 & 1.75 & -0.87 & -0.01 & 1.59 & 1.66 \\
\hline $2010-2$ & 1.75 & 1.75 & -0.40 & 0.00 & 2.01 & 1.71 \\
\hline $2010-3$ & 1.75 & 1.75 & -0.27 & 0.00 & 2.44 & 1.73 \\
\hline $2010-4$ & 1.75 & 1.75 & 0.00 & 0.01 & 2.91 & 1.77 \\
\hline $2011-1$ & 1.75 & 1.75 & 0.47 & 0.01 & 3.89 & 1.81 \\
\hline $2011-2$ & 2.00 & 1.75 & 0.73 & 0.00 & 4.18 & 1.82 \\
\hline 2011-3 & 2.25 & 2.00 & 0.70 & 0.01 & 4.31 & 2.06 \\
\hline $2011-4$ & 1.75 & 2.25 & 0.93 & 0.00 & 4.24 & 2.29 \\
\hline 2012-1 & 1.75 & 1.75 & 0.70 & -0.01 & 3.57 & 1.76 \\
\hline 2012-2 & 1.75 & 1.75 & 0.47 & -0.01 & 3.31 & 1.74 \\
\hline 2012-3 & 1.50 & 1.75 & 0.53 & -0.01 & 3.04 & 1.73 \\
\hline $2012-4$ & 1.50 & 1.50 & 0.30 & -0.02 & 2.74 & 1.46 \\
\hline 2013-1 & 1.50 & 1.50 & -0.13 & -0.03 & 2.30 & 1.41 \\
\hline 2013-2 & 1.00 & 1.50 & -0.60 & -0.03 & 2.04 & 1.42 \\
\hline 2013-3 & 1.00 & 1.00 & -0.67 & -0.02 & 1.77 & 0.94 \\
\hline 2013-4 & 0.75 & 1.00 & -1.20 & -0.02 & 1.50 & 0.94 \\
\hline 2014-1 & 0.75 & 0.75 & -1.33 & -0.02 & 1.00 & 0.67 \\
\hline $2014-2$ & 0.40 & 0.75 & -1.43 & -0.02 & 0.78 & 0.66 \\
\hline 2014-3 & 0.30 & 0.40 & -1.63 & -0.02 & 0.63 & 0.33 \\
\hline $2014-4$ & 0.30 & 0.30 & -1.83 & -0.01 & 0.56 & 0.25 \\
\hline 2015-1 & 0.30 & 0.30 & -2.33 & -0.02 & 0.59 & 0.25 \\
\hline 2015-2 & 0.30 & 0.30 & -1.83 & -0.01 & 0.58 & 0.25 \\
\hline $2015-3$ & 0.30 & 0.30 & -1.93 & -0.01 & 0.61 & 0.27 \\
\hline $2015-4$ & 0.30 & 0.30 & -1.87 & 0.00 & 0.66 & 0.28 \\
\hline $2016-1$ & 0.25 & 0.30 & -1.97 & -0.01 & 0.67 & 0.27 \\
\hline
\end{tabular}




\begin{tabular}{l|l|l|l|l|l|l}
\hline $2016-2$ & 0.25 & 0.25 & -2.07 & 0.00 & 0.76 & 0.24 \\
\hline $2016-3$ & 0.25 & 0.25 & -1.73 & 0.00 & 0.88 & 0.25 \\
\hline $2016-4$ & 0.25 & 0.25 & -1.27 & 0.01 & 1.03 & 0.27 \\
\hline $2017-1$ & 0.25 & - & -0.23 & 0.00 & - & - \\
\hline $2017-2$ & 0.00 & - & -0.47 & 0.01 & - & - \\
\hline $2017-3$ & 0.00 & - & -0.57 & 0.02 & - & - \\
\hline $2017-4$ & 0.00 & - & -0.57 & 0.02 & - & - \\
\hline
\end{tabular}

\section{Appendix 2 - Table of Results}

Table-1. United Kingdom

Model One: United Kingdom

\begin{tabular}{l|l|l}
\hline Natural Rate & Output Gap & Inflation Gap \\
\hline $\mathbf{0 . 0 4}$ & $\mathbf{0 . 1 6}$ & $\mathbf{1 . 2 4}$ \\
\hline$\left(13.3 ; 7.2 \times 10^{-25} ; 0.003\right)$ & $(1.8 ; 0.07 ; 0.09)$ & $\left(7.5 ; 1.4 \times 10^{-11} ; 0.17\right)$ \\
\hline Values in parentheses (t-Stat; p-value; Standard Error) & \\
\hline $\mathrm{R}^{2}:$ O.37; Adjusted R $\mathrm{R}^{2}$ 0.36; Significance F: $32.60\left(6.67 \times 10^{-12}\right)$ & \\
\hline
\end{tabular}

Table-2. United Kingdom - Including lagged interest rate variables $\left(\mathrm{i}_{\mathrm{t}-1}\right)$

\begin{tabular}{|c|c|c|c|}
\hline \multicolumn{4}{|c|}{ Model Two: United Kingdom (Lagged Values of Interest Rate) } \\
\hline Natural Rate & Output Gap & Inflation Gap & $\mathbf{i}_{\mathrm{t}-1}$ \\
\hline-0.00044 & -0.047 & -0.0042 & 0.99 \\
\hline$(-0.55 ; 0.58 ; 0.0008)$ & $(-0.29 ; 0.77 ; 0.014)$ & $(-1.41 ; 0.16 ; 0.033)$ & $\left(65.6 ; 4.39 \times 10^{-91} ; 0.015\right)$ \\
\hline \multicolumn{4}{|c|}{ Values in parentheses (t-Stat; p-value; Standard Error) } \\
\hline \multicolumn{4}{|c|}{$\mathrm{R}^{2}: 0.98 ;$ Adjusted R $\mathrm{R}^{2}$ : 0.98; F Value: $2281.41\left(3.2 \times 10^{-100}\right)$} \\
\hline
\end{tabular}

Table-3. Euro Area

\begin{tabular}{|c|c|c|}
\hline \multicolumn{3}{|l|}{ Model One: Euro Area } \\
\hline Natural ate & Output Gap & Inflation Gap \\
\hline 2.89 & 7.76 & 1.17 \\
\hline$\left(18.0 ; 7.66 \times 10^{-28} ; 0.16\right)$ & $(0.97 ; 0.33 ; 7.95)$ & $\left(6.66 ; 5.4 \times 10^{-28} ; 0.17\right)$ \\
\hline \multicolumn{3}{|c|}{ Values in parentheses (t-Stat; p-value; Standard Error) } \\
\hline \multicolumn{3}{|c|}{$\mathrm{R}^{2}: 0.47 ;$ Adjusted $\mathrm{R}^{2}: 0.45 ; \mathrm{F}$ Value: $30.09\left(4.01 \times 10^{-10}\right)$} \\
\hline
\end{tabular}

Table-4. Euro Area - Including lagged interest rate variable $\left(i_{t-1}\right)$

\begin{tabular}{l|l|l|l}
\hline Model Two: Euro Area (Lagged Values of Interest Rate) \\
\hline Natural Rate & Output Gap & Inflation Gap & $\mathbf{i}_{\mathrm{t}-1}$ \\
\hline 0.08 & 2.57 & 0.05 & 0.95 \\
\hline$(0.72 ; 0.47 ; 0.10)$ & $(0.85 ; 0.40 ; 2.21)$ & $(1.16 ; 0.24 ; 0.06)$ & $(28.87 ;$ \\
& & & $0.03)$ \\
\hline
\end{tabular}

Values in parentheses (t-Stat; p-value; Standard Error)

$\mathrm{R}^{2}$ : 0.96; Adjusted $\mathrm{R}^{2}$ : 0.96 F Value: 539.90(0.004)

Source: Authors' estimations 